\title{
Cloning and consensus: Bill C-6
}

T

The news that Korean researchers succeeded in culturing embryonic stem cells using somatic cell nuclear transfer (SCNT) - a form of cloning that has huge potential for the treatment of chronic diseases and organ replacement - arrived as Canadian parliamentarians were achieving consensus on a bill that would prohibit such research from being conducted in this country (see pages 1086 and 1090). Canadian legislation governing stem cell research has lagged behind both the United States and Britain. In the US, federal funds may not be used to support the creation of embryos as a source of stem cells or to support SCNT research; federal funding for embryo stem cell research is available only for existing stem cell lines. As a result, leading researchers are leaving the US to work in other countries, and some universities, such as Harvard, have decided to forgo federal funding in order to escape federal laws governing research.

In the United Kingdom the law accepts the use of embryos in research, and therapeutic cloning research of the type carried out in Korea, in view of the potential benefit to others. Stem cell researchers must be licensed and are subject to regulation by a national agency. Some activities, however, such as implanting a cloned embryo in a human uterus, are liable to criminal prosecution.

Canadian legislation on reproductive technologies made a slow and difficult progress as it contended with ethical opposition from those who consider the allowable uses of human embryos to be too permissive and with pragmatic objections from the scientific and medical community that the law was too restrictive. As we write, a Senate committee has approved Bill C- $6^{1}$ without amendment, making passage of the bill on final reading a near certainty.

The "legislative vacuum" that prevailed while Bill C-6 and its precursors limped through Parliament has had an inhibiting effect on Canadian research. Despite the existence of guidelines formulated by the Canadian Institutes of Health Research, there was sufficient uncertainty to bring funding of research that involves therapeutic cloning research to a standstill. Under the new legislation (cast in the mould of the CIHR guidelines), Canadian researchers will still be at a disadvantage in a competitive field. Attracting young researchers, retaining established researchers, and competing for international research funding will be difficult.
Certainly, the spectacular advances in genetic research from Dolly in 1997 to the publication of the near-complete genome in 2001 to the experiment in Seoul - challenge our perceptions of ourselves as human beings, forcing us as individuals and a society to ponder a number of imponderables. When does a human being become a human being? What do we mean when we accord a gamete, zygote or embryo human dignity? Do these human life forms have rights? Are those rights greater than that of the potential beneficiaries of new research?

The new legislation will set up an Assisted Human Reproduction Agency to review research applications and to license all fertility clinics in Canada for the first time. The objectives of licensing will prevent the exploitation of women (as paid donors or surrogates), to preclude commerce in gamete donation, and to supervise the use of unwanted embryos created in vitro for the purpose of reproduction (with appropriate consents) for use in research to develop embryonic stem cells. Penalties, including imprisonment, for prohibited activities will be imposed under the Criminal Code.

Physicians, researchers, religious leaders, parliamentarians and others have all found faults in Bill C-6, and some have actively opposed its passage. The attention given to the ethical challenges of stem cell research, cloning and surrogacy and the criminalization of violations embedded in the law have drawn attention from the bill's intent to ensure the safe, ethical and consistent delivery of reproductive services.

There can be no perfect consensus on the metaphysical questions subsumed by legislation on reproductive technologies and related research. If Bill C-6 were blocked in the Senate it would likely be several years before any Canadian government would tackle the problem again. Lacking perfect agreement, we can as a society nonetheless consent to a reasonable compromise. The passing of Bill C-6 will at least deliver researchers from a regulatory limbo, and will minimize the harms of assisted human reproduction. CMA7

\section{Reference}

1. Bill C-6, An Act Respecting Human Reproduction and Related Research, 3rd sess, 37th Parl, 2004 (referred to the House of Commons for 3rd reading, Mar 3 , 2004). 